\title{
Which firms benefit from foreign direct investment? Empirical evidence from Indonesian manufacturing
}

\author{
Suyanto ${ }^{a}$, Ruhul Salim ${ }^{\text {b,* }}$, Harry Bloch ${ }^{b}$ \\ ${ }^{a}$ Faculty of Economics, University of Surabaya, East Java, Indonesia \\ ${ }^{b}$ Curtin Business School, Curtin University, Perth, WA 6845, Australia
}

\section{A R T I C L E I N F O}

Article history:

Received 22 November 2012

Received in revised form 8 May 2014

Accepted 11 May 2014

Available online 19 May 2014

\section{JEL classification:}

D24

D29

F23

Keywords:

Foreign direct investment

Spillover effects

Technical efficiency

Stochastic production frontier

Indonesia

\begin{abstract}
A B S T R A C T
Despite growing concern regarding the productivity benefits of foreign direct investment (FDI), very few studies have been conducted on the impact of FDI on firm-level technical efficiency. This study helps fill this gap by empirically examining the spillover effects of FDI on the technical efficiency of Indonesian manufacturing firms. A panel data stochastic production frontier (SPF) method is applied to 3318 firms surveyed over the period 19882000. The results reveal evidence of positive FDI spillovers on technical efficiency. Interesting differences emerge however when the samples are divided into two efficiency levels. High-efficiency domestic firms receive negative spillovers, in general, while lowefficiency firms gain positive spillovers. These findings justify the hypothesis of efficiency gaps, that the larger is the efficiency gap between domestic and foreign firms the easier the former extracts spillover benefits from the latter.
\end{abstract}

(c) 2014 Elsevier Inc. All rights reserved.

\section{Introduction}

The spillover effects of foreign direct investment (FDI) have been a major concern for researchers and policy makers during the last two decades. A number of studies have examined the spillover effects of FDI on domestic firm productivity (Chakraborty \& Nunnenkamp, 2008; Haddad \& Harrison, 1993; Hu \& Jefferson, 2002; Javorcik, 2004; Liang, 2007; Negara \& Firdausy, 2011; Takii, 2005, 2011). These studies provide some useful insights regarding the evidence of the spillover benefits and offer some recommendations to maximize the benefits. However, most existing studies exclude technical efficiency and focus mainly on technology, ignoring that the FDI presence in host countries is the impetus for efficiency improvement through competition and demonstration effects (Wang \& Blomstrom, 1992). A study of FDI spillover effects on firm-level technical efficiency is important to provide evidence as to whether the large amount of FDI inflows generate positive externalities to domestic firms through efficiency improvement, thus indicating whether the spillover hypothesis is justified in the context of technical efficiency. Such a study can explore to what extent FDI can induce efficiency spillovers, and which firm types really benefit from the spillovers.

\footnotetext{
* Corresponding author at: School of Economics \& Finance, Curtin Business School, Curtin University, WA 6845, Australia. Tel.: +61 892664577; fax: +6192663026 .

E-mail address: Ruhul.Salim@cbs.curtin.edu.au (R. Salim).
} 